doi: $10.35757 /$ KiS.2019.63.3.12

\begin{tabular}{|c|c|c|}
\hline $\begin{array}{l}\text { KULTURA } \\
\text { i }\end{array}$ & $\begin{array}{l}\text { POLSKA AKADEMIA NAUK } \\
\text { KOMITET SOCJOLOGII }\end{array}$ & $\begin{array}{r}\text { ISSN 0023-5172 } \\
2300-195 \mathrm{x} \\
\end{array}$ \\
\hline SPOLECZENSTWO & 2019, nr 3 W SETNĄ ROCZNICĘ URODZIN ANT & ISKIEJ \\
\hline
\end{tabular}
$\begin{array}{lllllllllll}A & R & T & Y & K & U & £ & Y\end{array}$
I
$\begin{array}{llllllllll}\mathrm{R} & \mathrm{O} & \mathrm{Z} & \mathrm{P} & \mathrm{R} & \mathrm{A} & \mathrm{W} & \mathrm{Y}\end{array}$

PAWEE BAGIŃSKI

Uniwersytet Warszawski

\title{
FEMINIZM, MĘSKOŚĆ I KULTURA EMOCJONALNA MĘŻCZYZN IDENTYFIKUJĄCYCH SIĘ JAKO FEMINIŚCI*
}

Choć słowo „feminista” zadomowiło się w polskojęzycznej publicystyce i dziennikarstwie lifestylowym, dotychczas opublikowano tylko jedno naukowe opracowanie poświęcone feministom (Golińska 2008). Znacznie większym zainteresowaniem badaczy i badaczek cieszyła się męska tożsamość i jej przemiany (zob. np. Arcimowicz 2008; Kwaśny 2009; Ciaputa, Wojnicka 2011; Kluczyńska, Wojnicka 2015). Wzrost popularności niektórych postulatów feministycznych, obserwowany w Polsce od początku XXI wieku, skłania do krytycznego przyjrzenia się grupie heteroseksualnych mężczyzn identyfikujących się jako feminiści (zob. hooks 2004). Podejmuję tu próbę analizy wpływu samoidentyfikacji z feminizmem mężczyzn z klasy średniej na ich opinie dotyczace zagadnienia feminizmu, płci i związanej z nią kultury emocjonalnej. W tym celu omawiam teorie feministyczne, które problematyzują pojęcie męskości i pozycję mężczyzn w ruchu feministycznym. Przedstawiam także krytyczne teorie męskości, ze szczególnym uwzględnieniem badań dotyczących związków między płcią a emocjonalnością. Na podstawie wywiadów z feministami rekonstruuję niektóre ze społecznych uwarunkowań procesu internalizacji przez

Adres do korespondencji: plbaginski@gmail.com; ORCID: 0000-0002-1804-2247

* Artykuł powstał na podstawie pracy licencjackiej obronionej w Instytucie Socjologii Uniwersytetu Warszawskiego w 2015 roku. Promotorem pracy był Adam Ostolski. Za pomoc w nawiązaniu kontaktów z częścią badanych i pracę nad tekstem dziękuję Joannie Erbel. 
mężczyzn samoidentyfikacji feministycznej. Następnie analizuję dostrzeżone w tej grupie definicje feminizmu i męskości, krytykę męskiej dominacji, koncepcji kryzysu męskości oraz socjalizowania mężczyzn do patriarchalnej kultury emocjonalnej. Na podstawie tych rozważań wyprowadzam wnioski dotyczące przemian tożsamości płciowej i kultury emocjonalnej mężczyzn w obliczu emancypacji kobiet.

\section{MĘSKOŚĆ I MĘŻCZYŹNI W NIEKTÓRYCH TEORIACH FEMINISTYCZNYCH}

Problematyzacja pojęcia męskości stała się istotnym zagadnieniem radykalnego feminizmu drugiej fali, który głównej przyczyny opresji kobiet upatrywał w męskiej dominacji opartej na patriarchalnych strukturach społeczeństwa (Tong 2002, s. 65). Męska dominacja jest formą przemocy symbolicznej zakorzenionej w przedświadomej fazie percepcji, która strukturyzuje relacje mężczyzn i kobiet (Bourdieu 2004, s. 55). Feminizm radykalny $\mathrm{w}$ tradycji anglosaskiej jest dzielony, ze względu odmienne ujęcie problemu płci kulturowej, na feminizm radykalno-libertariański i radykalno-kulturowy (Tong 2002, s. 64). Gayle Rubin (1975, s. 159) system płci biologicznej i płci kulturowej definiowała jako zestaw ustaleń, za pomocą których społeczeństwo przekształca biologiczny charakter seksualności w produkt działalności ludzkiej, naturalizując w ten sposób społecznie wytwarzaną męskość i kobiecość. W oświeceniowo zorientowanym feminizmie radykalno-libertariańskim pojęcie kobiecości traktowano jako ograniczenie kobiety na drodze do osiągnięcia pełni człowieczeństwa, co wiązano $z$ androgyniczną koncepcją "osoby” wykraczającej poza binarny system męskości/kobiecości (Tong 2002, s. 66). Z kolei feminizm radykalno-kulturowy stawiał sobie za cel ochronę kobiecości przed tradycyjnie rozumianymi „męskimi wartościami” i postulował tym samym pewną formę separatyzmu płciowego, który miał zapewnić wspólnocie kobiet bezpieczeństwo w świecie męskiej dominacji (Tong 2002, s. 116). Obydwa nurty radykalnego feminizmu łączyła tendencja do polaryzowania różnicy między płciami, co służyło wyodrębnieniu właściwości charakterystycznych dla męskości i kobiecości.

Opis tych właściwości był rozwijany w feminizmie kulturowym, który koncentrował się na różnicach w psycho-moralnym rozwoju męskiej i kobiecej psychiki. W książce Innym głosem. Teoria psychologiczna a rozwój kobiet Caroll Gilligan (2015) opisuje dwa typy rozumowań moralnych, które aktualizują się w toku socjalizacji do płci kulturowej: kobieca etyka troski i męska etyka sprawiedliwości. Nie interesuje mnie tutaj krytyka pseudosystemowej dychotomii między męską racjonalnością i indywidu- 
alizmem a kobiecą emocjonalnością i wspólnotowością. Dla dalszego wywodu istotny jest wysnuty przez Gilligan wniosek, że kobiety częściej są socjalizowane do rozumienia problemów moralnych $z$ uwzględnieniem więzi międzyludzkich oraz potrzeb, pragnień i interesów innych osób; mężczyźni natomiast do autonomii, idei sprawiedliwości oraz praw uniwersalnych (zob. Tong 2002, s. 205). Zarówno feminizm kulturowy, jak i feminizm radykalny diagnozowały systemową opresję ze względu na płeć, w której kobiecość była funkcjonalnie podporządkowana męskości. Przekonanie o istocie „męskości” i „kobiecości” przywołuje nieproduktywny spór o esencjalizm płciowy, powstały w efekcie swoistego odczytania teorii francuskich feministek drugiej fali w Stanach Zjednoczonych (Bednarek 2014, s. 18-20). Tymczasem pojęcie różnicy płciowej, którym posługiwała się Luce Irigaray (1993), opisuje mechanizm wytwarzania relacyjnej tożsamości płciowej w perspektywie przekraczającej działanie systemu sex i gender, bez różnicowania tego, co materialne i kulturowe (Bednarek 2014, s. 18).

Redukcjonistyczna diagnoza systemowej opresji kobiet jedynie ze względu na zmienną „płeć” została przekroczona w feminizmie intersekcjonalnym, który wskazuje na współwystępowanie różnych typów opresji. Według przedstawicielki tego nurtu, amerykańskiej filozofki i aktywistki publikującej pod pseudonimem bell hooks, określanie przez liberalne i radykalne feministki feminizmu jako „zadania dla kobiet” wzmacniało ideologię seksistowską. „Ponieważ to głównie mężczyźni podtrzymują i wspierają seksizm i seksistowską opresję - pisze bell hooks (2013, s. 113) - można je skutecznie usunąć tylko pod warunkiem, że mężczyźni wezmą odpowiedzialność za zmianę męskiej świadomości oraz świadomości społeczeństwa jako całości". W myśl kultowego dla drugiej fali feminizmu sloganu „osobiste jest polityczne” domena polityczności wykracza poza liberalną sferę publiczną i obejmuje także relacje oraz praktyki w sferze prywatnej (hooks 2013, s. 58). Feminizm w tej perspektywie jest krytyczną świadomością polityczną, która postuluje konieczność jednoczesnego zniesienia przyczyn różnych typów opresji (hooks 2013, s. 59).

Przemoc symboliczna zmusza osoby podporządkowane do utożsamienia się z racjami grupy dominującej. W polityce genderowej oznacza to socjalizowanie kobiet i mężczyzn do reprodukowania schematu męskiej dominacji, z którego szczególnie korzyści czerpią heteroseksualni mężczyźni. Istotne jest więc rozpoznanie wartości i korzyści, które sprawiają, że mężczyźni identyfikują się z postulatami feministycznymi. 


\section{MĘŻCZYŹNI I MĘSKOŚĆ - CZY OPRÓCZ KAPITALIZMU KTOŚ JEST W KRYZYSIE?}

Według jednej z najbardziej wpływowych socjolożek męskości, Raewyn Connell (2005, s. 44), „męskości są konfiguracjami praktyk zorganizowanymi przez relacje genderowe". W tej definicji uwage zwraca rozumienie męskości jako ucieleśnionych praktyk reprodukowanych $\mathrm{w}$ relacjach władzy, nie zaś jako psychologicznej identyfikacji z koncepcją męskości (de Boise 2015, s. 48). Kolejne fale feminizmu stopniowo podmywały warunki brzegowe patriarchalnej męskości, która - socjalizowana jako rola płciowa wiążąca ze sobą ustalone cechy charakteru, skłonności i zachowania miała zapewnić stabilność i przewidywalność instytucji społecznych poprzez normalizowanie zachowania jednostek (Connell 2005, s. 22-23). Connell wskazała, że nie istnieje jeden proces socjalizacji do męskości, i odwołując się do terminologii Antonia Gramsciego, sformułowała teorię męskości hegemonicznej wobec innych męskości, która „ucieleśnia aktualnie uznawaną odpowiedź na problem legitymizacji patriarchatu". Zwróciła $\mathrm{w}$ ten sposób uwagę na strukturalne uwarunkowania praktyk genderowych, a zarazem ich zmienność w czasie (Connell 2005, s. 77).

Za główną relację władzy w sferze męskości w społeczeństwach Zachodu końca XX wieku australijska socjolożka uznaje podporządkowaną pozycję homoseksualnych mężczyzn (Connell 2005, s. 78). W tej relacji funkcję regulatywną pełni utrzymywana wsród heteroseksualnych mężczyzn atmosfera homohisterii na punkcie zachowania, które może być uznane za właściwe homoseksualistom - ocenia Eric Anderson (2009, s. 95-97). Ze względu na zwiększanie widzialności osób homoseksualnych i rozszerzanie ich praw rewiduje ustalenia Connell i proponuje teorię męskości inkluzywnej, która zakłada niehegemoniczne współistnienie różnych typów męskości. Interesujące, że zarówno relacyjna teoria męskości hegemonicznej - mimo kluczowej roli praktyk w definicji męskości Connell — jak i teoria męskości inkluzywnej Andersona zakłada konstruowanie kategorii męskości, w które trudno jest wpisać konkretnych mężczyzn (Hearn 2018, s. 251). Wątpliwości Jeffa Hearna odzwierciedla tytuł pracy Od męskości hegemonicznej do hegemonii mężczyzn, w której brytyjski socjolog zamiast mnożenia typologii męskości proponuje badanie mężczyzn jako kategorii społecznej produkowanej w porządku płci, a zarazem jako aktorów materialno-dyskursywnych praktyk społecznych (Hearn 2018, s. 252-253).

Do typologii Andersona sięgam w celu przywołania opozycji obecnej w publicystycznym dyskursie o kryzysie ortodoksyjnej odmiany męskości, 
opartej na dualizmie ról płciowych, podporządkowywaniu innych mężczyzn, kobiet i dzieci, a także nakazie kontroli ekspresji emocji kojarzonych z zależnością społeczną. Wobec kryzysu tak rozumianej męskości upowszechnia się relacyjny typ męskości inkluzywnej, który zakłada równość i partnerstwo mężczyzn oraz kobiet, niezależnie od orientacji seksualnej, akceptuje androgyniczność oraz wolność ekspresji niezależną od płci kulturowej. Tak ujęta „nowa męskość” nie podporządkowuje sobie osób nieheteronormatywnych i jest zorientowana na wyjście poza logikę męskiej dominacji, która poprzez reprodukcję w schematach percepcji i dyspozycji naturalizuje sposób myślenia grupy dominującej i utrwala patriarchalne urządzenie społeczeństwa (Bourdieu 2004, s. 47). Interpretowanie rekonfiguracji wzorów socjalizacji mężczyzn w kategoriach kryzysu zakłada częściową utratę przez mężczyzn uprzywilejowanej pozycji wobec kobiet, co następuje w efekcie działania polityk antydyskryminacyjnych. Warto dodać, że władza nad kobietami i przemoc wobec kobiet funkcjonują między innymi jako sposób kompensowania frustracji wynikającej ze strukturalnej degradacji w gospodarce neoliberalnej mężczyzn z klasy ludowej i średniej. Właśnie do tej emocji skutecznie odwołują się radykalnie prawicowe ruchy społeczne (Kimmel 2013).

\section{KULTURA EMOCJONALNA I UPŁCIOWIONE EMOCJE}

Emancypacja kobiet w społeczeństwach zachodnich wywołała strukturalne przesunięcia $w$ relacjach genderowych i związanych $z$ nimi kulturach emocjonalnych (Wouters 2004). Pojęcie kultury emocjonalnej odnoszę - za Mają Sawicką (2015) — do społecznego ładu emocjonalnego, czyli sposobu, w jaki fizjologiczne pobudzenie jednostki jest kształtowane i porządkowane na poziomie zbiorowości przez normy wyrażania emocji. Steven Gordon (1990, s. 146) definiuje kulturę emocjonalną jako wytwarzane przez strukturę społeczną (1) normy dotyczące emocji, (2) słowa, jakimi mówi się o emocjach, (3) przekonania na temat emocji. Ta trzyelementowa definicja pozwala uchwycić subwersywny wobec tradycyjnie rozumianej męskości sposób waloryzowania emocji przez feministów. Polega on na nieutożsamianiu ich z kobiecością.

Różnice płciowe w ekspresji emocji są warunkowane przez odmienne doświadczenia kobiet i mężczyzn we właściwych im światach społecznych (Lutz 2012, s. 49). W analizie związków między feminizmem i emocjonalnością interesujący jest zwłaszcza dyskurs waloryzujący emocjonalność jako progresywną siłę społeczną. W nurcie krytycznych studiów nad mężczyznami i męskościami (CSMM - Critical Studies on Man 
and Masculinities) zwraca się uwagę, że łączenie ze sobą emancypacji kobiet i emancypacji emocjonalnej mężczyzn może odtwarzać seksistowski stereotyp o większej emocjonalności kobiet (de Boise 2017). Perspektywa feministów ma potencjał badawczy w odniesieniu do kulturowych procesów upłciowienia emocji integrujących i autonomizujących, ponieważ $\mathrm{w}$ ich doświadczeniu przecinają się pozornie różne systemy wartości płci i polityki emancypacji kobiet (Gilligan 2015).

\section{KIM SĄ FEMINIŚCI W OPISYWANYM BADANIU?}

Wiosną 2015 roku przeprowadziłem w Warszawie dziewięć indywidualnych wywiadów pogłębionych z białymi mężczyznami identyfikującymi się jako feminiści, którzy popierają antyseksistowski ruch feministyczny ${ }^{1}$. Zbiorowość badanych została zawężona — na zasadzie doboru celowego do osób bezsprzecznie korzystających z męskiej dominacji, czyli heteroseksualnych mężczyzn, $z$ wyjątkiem jednego rozmówcy, który określił się jako osoba biseksualna. Wstępny wywiad pozwolił określić cechy badanych jako charakterystyczne dla przedstawicieli klasy średniej, o częściowo prekarnej kondycji, należących do wielkomiejskich postępowych środowisk. Z wyjątkiem jednej osoby mieszkającej w Gorzowie Wielkopolskim i jednej osoby z wykształceniem średnim badani byli mieszkańcami Warszawy, uczącymi się lub mającymi wyższe wykształcenie. Warto zaznaczyć, że w czasie przeprowadzania wywiadów „feminista” jako samookreślenie mężczyzn miało w Polsce charakter stosunkowo awangardowy, co znajduje odzwierciedlenie w klasowym obciążeniu badanej zbiorowości. Trzech badanych uczestniczyło w zorganizowanym ruchu profeministycznym: dwóch należało do grupy „Głosy przeciw przemocy”, podnoszącej świadomość mężczyzn, dwóch współpracowało z magazynem „Codziennik feministyczny”2.

Analizowanie związków feminizmu, męskości i kultury emocjonalnej na podstawie opinii badanych wymaga zastanowienia nad wiarygodnością tych deklaracji i zestawienia ich z przejawami codziennego zachowania (Butler 2008; por. de Boise 2015, s. 48). Moje przedsięwzięcie ma zatem przede wszystkim charakter eksploracyjny i należy je traktować jako wstęp do dalszego badania roli polityki tożsamości, relacji władzy między płciami i upłciowienia emocji $\mathrm{w}$ perspektywie materialno-dyskursywnych praktyk społecznych.

${ }^{1}$ Wypowiedzi kodowałem według formatu „A_18”, w którym litera oznacza liczbę porządkową, a cyfry wiek badanego.

${ }^{2}$ Na temat mężczyzn zaangażowanych $w$ antyprzemocowy ruch feministyczny zob. Messner, Greenberg, Peretz 2015. 


\section{FEMINIZM MĘŻCZYZN}

Można stwierdzić, że na samoidentyfikację feministów składają się w myśl teorii socjalizacji Bergera i Luckmanna (1983) - trzy niewykluczające się procesy: reakcja na socjalizację pierwotną w dzieciństwie, efekt kontaktów z otoczeniem społecznym i dyskursem feministycznym w socjalizacji wtórnej oraz resocjalizacja.

W przytoczonych przez respondentów historiach rodzinnych relacje genderowe między znaczącymi innymi $z$ dzieciństwa układały się według dwóch scenariuszy. W pierwszym mężczyźni mieli tolerancyjnych, liberalnych rodziców pozostających ze sobą w relacji partnerskiej lub choć jednego $z$ rodziców charakteryzowała wrażliwość społeczna i z jego postawą się zidentyfikowali. Wpływ socjalizacji pierwotnej był szczególnie istotną zmienną warunkującą utożsamienie się mężczyzn z feminizmem: mi się wydaje, że ja zawsze bytem feminista (I_56); całe życie czutem sie feminista (D_25). W wypowiedziach wielokrotnie pojawiała się matka jako osoba, która uczyła rozumienia problemów moralnych $z$ uwzględnieniem różnicy perspektyw i etyki troski o innych (Gilligan 2015):

Mama wyksztatcita we mnie tolerancje, nieocenianie nikogo. Gdy jako 16-latek palnątem coś po złości, to mama mówiła, żebym nie traktował ludzi źle i nie wyśmiewat się, na przykład że ktoś jest otyty (G_44).

W drugim scenariuszu feminizm był reakcją sprzeciwu wobec patriarchalnych relacji panujących $\mathrm{w}$ domu rodzinnym, z którym badany nie chciał się identyfikować. Feminizm kontestuje zastany ład społeczny. Nie dziwi zatem, że feminiści związani są również z innymi radykalnymi grupami: [zostałem feministą] przez to, że trafitem do środowiska punkowego $i$ anarchistycznego (F_38).

Ważnym momentem w kształtowaniu się tożsamości feministy jest nawiązanie relacji $z$ osobami zaangażowanymi w ruch feministyczny lub poznanie teorii feministycznej. Warto zaznaczyć, że internalizacja w socjalizacji wtórnej zasadniczo nie przynosi tak silnej identyfikacji z postawami innych jak relacje ze znaczącymi innymi w dzieciństwie (Berger, Luckmann 1983, s. 219-21). Rozwijanie feministycznej samoidentyfikacji u mężczyzn można zatem uznać za następstwo i przedłużenie otrzymanego wychowania: Czytając o feminizmie uświadomitem sobie własne feministyczne zachowania (B_24).

Utożsamienie $z$ feminizmem może też być następstwem ważnych wydarzeń $\mathrm{w}$ życiu mężczyzn, takich jak wejście $\mathrm{w}$ związek $\mathrm{z}$ feministką lub 
skuteczna psychoterapia. „Konwersję na feminizm” uznaję za rodzaj resocjalizacji, gdyż oznacza ona rezygnację z części dotychczasowych relacji społecznych: nie da się nie być feminista w moim otoczeniu (C_24). Osoby „nawrócone" na feminizm entuzjastycznie opowiadały o tym, jak ich życie zmieniło się na korzyść w stosunku do przeszłości, którą reinterpretowali jako okres niejasny, często także negatywnie: przeszedtem jak $w$ „Gwiezdnych wojnach" z ciemnej strony mocy na jasna. To mnie cieszy, że tak się rozwijam w wieku czterdziestu lat (G_44). Berger i Luckmann (1983, s. 245) piszą: „przełom biograficzny daje się zidentyfikować po poznawczym oddzieleniu ciemności i światła”. Przed „konwersją na feminizm” badani nie określali się jako przeciwnicy feminizmu, mieli do niego stosunek obojętny. W mocy pozostaje zatem rozpoznanie formacyjnej roli, jaką $\mathrm{w}$ procesie internalizowania feminizmu przez mężczyzn pełnią relacje władzy między rodzicami i socjalizowanie w dzieciństwie do etyki troski.

Feminiści definiowali feminizm na dwa sposoby: jako ruch społeczny i polityczny walczący o prawa kobiet oraz jako równościową postawę etyczną i antyseksistowską perspektywę poznawczą. Takie dwupostaciowe definiowanie feminizmu koresponduje z podziałem na prywatny i publiczny wymiar polityczności: Znam mase facetów, którzy nie poczuwają się do bycia członkami żadnego ruchu feministycznego, ale sa feministami w postawie osobistej (I_56). Podobieństwo między feminizmem jako ruchem politycznym i postawą w kontaktach osobistych polega na aktywnym sprzeciwie wobec reprodukcji męskiej dominacji: Odkrycie feminizmu wiązało się dla mnie ze zrobieniem sobie w bani iluś tam blokad odnośnie rzeczy, które sa złe po prostu (B_24). Zawarte $\mathrm{w}$ wypowiedziach respondentów definicje feminizmu jako ruchu politycznego nie różniły się od definicji z teorii feministycznych tworzonych przez kobiety (zob. Tong 2002). Nieścisłością jest zatem mówienie o „męskim” feminizmie - są raczej mężczyźni popierający feminizm (hooks 2008, s. 128). Definicja feminizmu jako postawy w kontaktach osobistych jest ważna ze względu na problem wiarygodności samoidentyfikacji z feminizmem, aktualizującej się w praktykach mężczyzn określających się jako feminiści.

Reakcje kobiet wobec feministów w przeważającej części były opisywane przez respondentów jako pozytywne. Mimo to dwóch z nich przestało publicznie określać się jako feminiści - argumentowali to niechęcią do zawłaszczania pozycji kobiet $\mathrm{w}$ ruchu politycznym:

Zauważyłem taka tendencję, że jak ja mówiłem, że jestem feminista, to było jakieś wydarzenie. A moje koleżanki które sa feministkami od lat — to nie robi wrażenia (F_38). 
Kilku badanych wprost krytykowało chwytliwą narrację o „męskim feminizmie", która wynosi samą obecność feministów nad pracę feministek. Polityka widzialności $\mathrm{w}$ dyskursie medialnym reprodukuje tradycyjny porządek płci, w którym mężczyźni są predestynowani do zajęcia pozycji lidera i eksperta. Jest to przykład patriarchalnej dywidendy, czyli korzyści płynących z męskiej dominacji dla mężczyzn jako osób należących do grupy hegemonicznej (Connell 2009, s. 142).

Przez feministki trzeciej fali separatyzm płciowy radykalnego feminizmu był krytykowany za budowanie negatywnego stereotypu feminizmu jako ruchu antymęskiego (hooks 2013, s. 112). Aby określić, co oprócz dyskursu „wojny płci” może zniechęcać mężczyzn do utożsamiania się $z$ feminizmem, poprosiłem respondentów o stworzenie stereotypu feministy. $Z$ tych propozycji wyłania się postać mężczyzny z klasy średniej o określonych poglądach politycznych oraz dyskusyjnej tożsamości płciowej i orientacji seksualnej:

Zdecydowanie lewicowe poglady, zwiazany ze sztuka, klasa średnia, ekscentryk, indywidualista (C_24).

Facet nie do końca męski (I_56).

Wyglada trochę jak kobieta, taki jest zdziwaczaty - może nawet homoseksualny często, emocjonalny, uczuciowy (F_38).

Niektórzy zwracali uwagę na krytykę domniemanej autokreacji feministów: wielu facetów zarzuca mi to, że afiszuję się z feminizmem albo angażuje się $w$ ruch tylko po to, żeby podrywać feministki (F_38). Wiarygodność feministy bierze się $z$ procesu stawania-się-sojusznikiem kobiet na podstawie codziennego postępowania i ograniczania męskich przywilejów (Messner, Greenberg, Peretz 2015, s. 168). Tak rozumiany feminizm mężczyzn nie reprodukujących męskiej dominacji jest znacznie powszechniejszy niż samoidentyfikacja $z$ feminizmem.

Podszedł do mnie po dyskusji [na temat równości płci i feminizmu] $w$ Legnicy mężczyzna, ojciec dwójki dzieci. Być może on nie ma potrzeby takiego się nazywania. On to zrozumiat bez aparatu pojęciowego, z życia, ze swojej empatii (H_52).

Sukces feminizmu jako ruchu politycznego zależy od postawy etycznej i perspektywy poznawczej „zwykłych mężczyzn”, którzy niekoniecznie określają się jako feminiści, lecz są wrażliwi na niesprawiedliwość społeczną i świadomi innych rodzajów opresji. Feministyczna samoidentyfikacja mężczyzn ma wymiar klasowy i nie musi korelować z „feministycznymi” zachowaniami w kontaktach osobistych. Klasowość przejawia się także W znajomości terminologii gender studies i opowiadaniu o feminizmie jako indywidualistycznym projekcie siebie: To jest projekt pracy intelektualnej, 
uczuciowej $i$ osobowościowej nad soba samym (H_52); ciagła i nieustająca praca nad soba (E_31).

Status mężczyzn będących feministami funkcjonalizuje ich rolę społeczną jako popularyzatorów i integratorów grup sprzeciwu wobec hegemonicznej polityki także ze względu na stereotypy płciowe, gdyż bezpiecznie można założyć, że innym mężczyznom łatwiej jest się zidentyfikować $z$ feministą niż feministką. To utożsamianie wydaje się jednak ograniczone do mężczyzn z klasy średniej i wyższej. Świadome poparcie dla postulatów feminizmu rozumianego jak ruch polityczny odróżnia feminizm mężczyzn określających się jako feminiści od feminizmu „zwykłych mężczyzn”, rozumianego jako nieseksistowska i krytyczna wobec męskiej dominacji postawa etyczna i perspektywa poznawcza w życiu codziennym.

\section{FEMINIŚCI WOBEC MĘSKOŚCI}

Podczas gdy badani chętnie opowiadali o feminizmie, temat męskości okazał się znacznie trudniejszy, podzielił feministów na grupę utożsamiającą się z pewną definicją męskości i grupę odrzucającą tę kategorię. Główny argument drugiej grupy polegał na utożsamieniu męskości z jej hegemoniczną odmianą, której przeciwstawiali wizję postpłciowego świata wolnego od różnicy płciowej: Nie posługuje się tą kategoria, do niczego nie jest mi ona potrzebna. Po prostu jestem człowiekiem (F_38). Umiarkowane stanowisko wobec kategorii męskości odwoływało się jednak do płci biologicznej: Bycie mężczyzna sprowadza się, może nie tylko i wytacznie, ale do funkcji biologicznych: posiadanie penisa, szybsze umieranie, posiadanie zarostu itd. (D_25). Odrzucenie kategorii męskości i wybór narracji pospłciowej lub akceptacja problematycznego faktu „bycia mężczyzną” wskazuje tu zatem na nieadekwatność systemu sex/gender do opisu tożsamości płciowej. Męskość nie pokrywa się w tym ujęciu z kategorią „bycia mężczyzną”, której z kolei nie da się sprowadzić do płci biologicznej. „Bycie mężczyzną” jest więc społecznym produktem różnicowania mężczyzn i męskich praktyk, do których można zaliczyć zarówno niektóre funkcje biologiczne, jak i korzystanie $z$ patriarchalnej dywidendy (Hearn 2018).

Ci, którzy byli ojcami (jeden z badanych był także dziadkiem), utożsamiali się z wizją relacyjnej męskości komplementarną z kobiecością „bycie ojcem” jako rola społeczna wymagająca wypracowania praktycznego stosunku do męskości. Feminiści-ojcowie zaproponowali kategorię bliską męskości inkluzywnej Erica Andersona, negocjowalną i nieostrą, która w wyniku rewolucji feministycznej uległa fundamentalnej redefinicji — zyskała otwartość na wiele form ekspresji: 
Pozytywna definicja męskości to jest to, że stawiam na budowanie emocjonalnych relacji z bliskimi czy innymi ludźmi, na uświadamianie sobie własnych przywilejów i niekorzystanie z nich na ile się da, i na ile świadomie je mogę zauważyć, na umiejętności przyznawania się do porażki i słabości, na próbach otwierania się (H_52).

Proces przekształcania męskości i „otwierania się” mężczyzn na wartości przypisywane kobietom znajduje odzwierciedlenie $\mathrm{w}$ wielu propozycjach teoretycznych. Jest to wspomniana męskość inkluzywna czy też męskość opiekuńcza, polegająca na odejściu od dominacji i agresji na rzecz troski i współzależności, które są oczekiwane od ojca dzielącego się z matką obowiązkami opiekuńczymi wobec dziecka (Elliott 2016). Takie, bliskie feminizmowi liberalnemu i kulturowemu, ujęcie męskości wyraża przekonanie o wielości form jej ekspresji i wzajemnym uzupełnianiu się męskości i kobiecości: Coraz więcej facetów widzi, że ta męskość nie ma jednej twarzy. To jest jak najbardziej pozytywne (F_38).

Opinie feministów na temat kryzysu męskości były zróżnicowane ze względu na wiek. Młodsi mężczyźni żartowali z tego określenia i dystansowali się od niego, podobnie jak od męskości rozumianej jako płeć kulturowa. Można zatem stwierdzić, że w kryzysie jest nie męskość jako taka, ale męskość patriarchalna i relacje władzy w porządku płci, które ulegają zmianom w wyniku walki o prawa kobiet. O realności kryzysu męskości w zdecydowany sposób wypowiedziało się dwóch najstarszych respondentów. Według nich, kryzys męskości wynika z tego, że mężczyźni nie wiedzą, jak ustosunkować się do zmiany relacji między płciami. Prowadzi to do zaburzenia tożsamości i poczucia zbędności, gdyż powszechność sztywnych ról płciowych wytwarzała schematy percepcyjne, które pozwalały automatycznie odnajdywać się w relacjach hegemonicznych (Bourdieu 2004, s. 46). Feminizm można zatem uznać za strategię przezwyciężania kryzysu męskości oznaczającego rozpad tradycyjnych form symbolicznych.

Ma tożsamościowy kryzys męskości można spojrzeć jako na efekt kryzysu patriarchatu w wymiarze ekonomicznym:

Mówienie o kryzysie męskości jest upłciawianiem ekonomicznej degradacji, której doświadczają coraz szersze rzesze zarówno mężczyzn, jak i kobiet (B_24).

Ta ciekawa wypowiedź wpisuje się $\mathrm{w}$ dyskurs feminizmu intersekcjonalnego, który zwraca uwagę na matrycę dominacji łączącą seksizm i klasizm. Postępująca od lat siedemdziesiątych w państwach rozwiniętych degradacja ekonomiczna osób z klasy ludowej i średniej jest utożsamiana z kryzysem tradycyjnej męskości: Świat ekonomiczny byt skonstruowany tak, że mężczyzna byt żywicielem rodziny. Wszystko to się rozsypało i mężczyźni zostali $w$ pustce (I_58). Aby usprawiedliwić degradację mężczyzn z klasy 
ludowej i średniej w neoliberalnej gospodarce, wykorzystuje się dyskurs wyrównywania szans kobiet na sukces i awans społeczny. W ten sposób dokonuje się komodyfikacja liberalnego feminizmu w biopolitycznych mechanizmach rynkowych, przy jednoczesnym antagonizowaniu mężczyzn na płaszczyźnie genderowej.

Feminiści, tak jak wszyscy mężczyźni, czerpią osobiste korzyści z męskiej dominacji. Przypadająca im w udziale patriarchalna dywidenda wywołuje przykre poczucie nieintencjonalnego przyczyniania się do reprodukowania męskiej dominacji: Oczywiście czuję się z tym niezręcznie (D_25); Próbuję z tym walczyć, ale nie wszystko się da usunąć. Źle się z tym czuję (H_52); Jade $z$ wyktadem do Gdańska i ja wiem, że mi proponuja honorarium prawdopodobnie o 1/3 wyższe, niż gdybym ja byt kobieta $z$ takim samym dorobkiem; $w$ takim sensie korzystam i czuję się z tym źle (I_56).

Świadomość niesprawiedliwości społecznej może skłaniać do zwiększania kontroli nad bezrefleksyjnym korzystaniem z patriarchalnych przywilejów. Jednocześnie feminiści zgodnie stwierdzali, że swobodniej czują się w gronie kobiet niż mężczyzn: Uważam że kobiety są lepsze, często sa madrzejsze, troskliwsze, bardziej liberalne (E_31); Lepiej mi się gada z kobietami, bo kobiety $w$ ogóle lepiej rozmawiaja $i$ chętniej rozmawiaja (I_56). Preferencja ta może wynikać $z$ niechęci do walki o dominację z innymi mężczyznami, a także z pozytywnego waloryzowania relacyjnej etyki troski.

\section{PŁEĆ I KULTURA EMOCJONALNA}

Socjalizacja do upłciowionych form ekspresji pewnych emocji (np. troski o innych jako emocji kobiecej, agresywnego gniewu jako emocji męskiej) reprodukuje system podporządkowania kobiet i hegemonii mężczyzn (Bourdieu 2004, s. 34; Hearn 2018). Emancypacji kobiet towarzyszą zatem przemiany w kulturze emocjonalnej mężczyzn, która strukturyzuje relacje genderowe (Gordon 1990, s. 146). Feminiści zgodnie stwierdzali, że socjalizacja kobiet czyni je bardziej świadomymi swoich emocji niż socjalizacja mężczyzn, którzy częściej mają problem z rozpoznaniem i zrozumiałym komunikowaniem emocji: [mężczyźni] maja fundamentalny problem. Nie mówia, nie potrafia (H_52). Ekspresja emocji przez kobiety również jest sankcjonowana przez kulturę patriarchalną: Sa zachowania, które sa im zabraniane, na przykład „nie śmiej się tak głośno, bo dziewczynie nie wypada" (A_18). Upłciowienie emocji jest zatem następstwem reprodukcji męskiej dominacji. Socjalizacja mężczyzn częściej skutkuje trudnościami w wyrażaniu emocji, które w patriarchalnej kulturze uważane są za oznakę słabości. 
Stabością jest nieumiejętność posługiwania się emocjami. Na tym polega kryzys męskości dzisiaj. Faceci maja życie spłaszczone przez to, że boją się zanurzyć w te emocje, które im się kojarzą z kobiecością (I_56).

Język hybrydyzacji płci w dyskursie o męskości świadczy o przesunięciach w kulturach emocjonalnych mężczyzn i kobiet (Bridges, Pascoe 2014; por. de Boise 2015, s. 60). W konsekwencji mężczyźni zyskują szerszy zakres ekspresji emocji, w mniejszym stopniu określony przez płeć. Poniższy cytat zawiera opis zmiany stosunku do emocjonalności w wyniku psychoterapii, pokazując zarazem interesujące współistnienie dwóch porządków narracyjnych:

Rozmawianie o emocjach nie byto u mnie standardem, więc siła rzeczy nauczyłem się po prostu o nich mówić. A te emocje we mnie sa, więc zazwyczaj jest tak, że albo kogośn napierdalam, żeby dać im upust [badany jest trenerem sztuk walki]. Albo idę się najebać. Więc mówienie o emocjach dużo daje. Ale to jest bardzo trudne, jeżeli większa część życia spędziteś o nich nie mówiąc (F_38).

Widzimy, że w wypowiedzi o słabo rozwiniętym języku emocji u osoby socjalizowanej na mężczyznę przy opisie czynności kojarzonych z rozładowywaniem emocji pojawiają się wulgaryzmy. Przykład ten pokazuje również, że analizie akceptowalnych praktyk ekspresji lepiej służy przestrzenna metafora współistnienia i nakładania się na siebie różnych kultur emocjonalnych niż następowania ich po sobie.

Feminizm pozwala mężczyznom na uniknięcie upłciawiania emocji i sprzyja uświadomieniu sobie uwarunkowania przez płeć praktyk radzenia sobie $z$ emocjami. Łączy się także $z$ dowartościowaniem sfery relacji międzyludzkich i większą wrażliwością społeczną: Będąc feministą, stajesz się bardziej wrażliwy na różne rzeczy, nie tylko na kobiety. Co też pewnie przeszkadza (E_31). Badani, którzy przeżyli „konwersję na feminizm”, zwracali uwagę, że dzięki pracy nad sobą czują się w większym stopniu samoświadomi i zadowoleni z siebie: Mam poczucie że intelektualnie mi to otworzyto oczy na coś strasznie ważnego, że miatbym bardziej jałowe życie bez tego odkrycia (H_52). Niezależnie od stosunku do kategorii męskości feminizm badanych idzie $w$ parze $z$ większą otwartością na zachowania podważające tradycyjnie męskie i kobiece kultury emocjonalne.

Słuszna wydaje się krytyczna ocena procesu „otwierania się” kultury emocjonalnej mężczyzn jako wehikułu antydyskryminacyjnej zmiany społecznej (de Boise, Hearn 2015; por. Anderson, McCormack 2016), co sugeruje optymistyczna narracja męskości inkluzywnej: Jeśli umiesz panować nad emocjami, to umiesz to przekuć $w$ sitę. Jeżeli nie umiesz, to one pokazuja twoja stabość (D_25). Badacze z kręgu CSMM zwracają uwagę, że dys- 
kurs „emocjonalnych mężczyzn” nie demontuje struktur męskiej dominacji, lecz może wspierać ich reprodukcję. W interesujący sposób pokazują to badania internetowych portali randkowych. Niektórzy heteroseksualni mężczyźni z tendencją do szczerego i emocjonalnego komunikowania się $\mathrm{z}$ kobietami $\mathrm{w}$ przypadku odrzucenia reagują agresywnie na podważanie ich męskiego przywileju, oskarżając kobiety o niedostrzeganie ich moralnej wyższości nad „tradycyjnymi” mężczyznami (de Boise 2017, s. 9-10). De Boise (2015, s. 58) trafnie argumentuje, aby nie łączyć tego typu zjawisk $z$ upowszechnieniem feminizmu, gdyż - jak argumentuje za Evą Illouz — dyskurs emocjonalnych mężczyzn, reprodukujący męską dominację, często pojawiał się w przeszłości, choćby w dziewiętnastowiecznej literaturze romantycznej.

\section{PODSUMOWANIE: PŁEĆ PO PRZEJŚCIACH}

Prywatny i publiczny wymiar polityczności znalazł odzwierciedlenie $\mathrm{w}$ dwojakim rozumieniu feminizmu w badanej grupie. Samoidentyfikacja mężczyzn $z$ feminizmem może być publiczną deklaracją poparcia dla postulatów ruchu feministycznego. Natomiast określanie feminizmu jako postawy etycznej oddaje problem reprodukowania męskiej dominacji w kontaktach osobistych. Feminiści i mężczyźni kierujący się wartościami równości płci są niezbędnymi „towarzyszami walki” i sojusznikami kobiet, gdyż niemożliwe jest osiągnięcie postulatów feministycznych bez ich współudziału (hooks 2013, s. 129). Popularyzacja feminizmu wśród mężczyzn, rozumiana jako budowanie poparcia dla walki o prawa kobiet oraz proces rozwijania samokontroli w sferze męskich przywilejów, podkreśla ważność i podtrzymuje aktualność sloganu „osobiste jest polityczne”.

Emancypacja kobiet wyłoniła kwestię tożsamości płciowej, przy czym poglądy feministów stanowią interesujący wskaźnik zmian w porządku płci. Chociaż badani odwoływali się do podziału na płeć biologiczną i kulturową, wątpliwości części z nich budziła nieadekwatność tych pojęć wobec doświadczenia płci. Bezdzietni respondenci utożsamiali męskość z jej hegemonicznym typem, który odrzucali na rzecz narracji postpłciowej lub akceptacji faktu społecznego „bycia mężczyzną” jako działania materialno-dyskursywnego porządku płci. Według feministów będących ojcami męskość była komplementarna z kobiecością, pozostając pozytywnym i istotnym elementem ich tożsamości płciowej.

Feminizm może zatem służyć przezwyciężeniu kryzysu męskości za sprawą nieutożsamiania się mężczyzn z tradycyjnym typem płci kulturowej - w myśl twierdzenia, że męskość nie równa się „byciu mężczyzną" 
(Hearn 2018). Odrzucając męskość hegemoniczną, feminiści uchylają regulatywną funkcję homofobii, co umożliwia różnym formom męskości funkcjonowanie poza relacjami dominacji (Kluczyńska, Wojnicka 2015, s. 2). Problemem kategorii męskości jest zatem utożsamianie $z$ jej hegemoniczną odmianą, gdyż w konsekwencji, paradoksalnie, może być ona bardziej krępująca niż kobiecość, która obejmuje większy wachlarz nieopresyjnych ról społecznych.

Feminizm zwiększa przyzwolenie na ekspresję emocji integrujących, zorientowanych na relacyjną etykę troski (Gilligan 2015). Feminiści krytykowali ograniczony kod ekspresji właściwy dla tradycyjnej kultury emocjonalnej, do której socjalizowani są mężczyźni. W efekcie emancypacji kobiet kultura emocjonalna mężczyzn z klasy średniej w mniejszym stopniu może być ograniczona przez płeć. Feminizm pozwala mężczyznom uświadomić sobie działanie mechanizmu upłciawiania emocji, daje wgląd w uwarunkowania przez płeć sposobów wyrażania emocji i łączy się z otwartością na zachowania podważające tradycyjnie męskie i kobiece kultury emocjonalne.

Feminizm jako nowoczesna myśl emancypacyjna obejmuje także emancypację mężczyzn z opresyjnej kultury emocjonalnej (hooks 2004). Umiejętność inteligentnego posługiwania się emocjami staje się dla mężczyzn kluczowa na rynku pracy we współzawodnictwie z kobietami:

W pewnym sensie feminizm $i$ obracanie się $w$ środowisku feministycznym, które jest samoświadome, zmusza mnie do pracy nad emocjami swoimi i emocjami innych, żeby być sprawniejszym człowiekiem (C_24).

Problematyka tu zarysowana wymaga pogłębionych badań nad zagadnieniami płci, klasy i zaangażowania społecznego. W czasie realizacji badania samoidentyfikacja mężczyzn $z$ feminizmem była zjawiskiem marginalnym, a w grupie badanych znaleźli się mężczyźni z klasy średniej, niemal wyłącznie mieszkający w Warszawie, wykształceni na humanistycznych i społecznych studiach wyższych. Tymczasem sukces feministycznych postulatów politycznych zależy od postawy etycznej i perspektywy poznawczej „zwykłych mężczyzn”, krytycznych wobec męskiej dominacji. W związku z tym warto, aby dalsze badania feminizmu mężczyzn dotyczyły materialno-dyskursywnych praktyk w próbie zróżnicowanej klasowo. Drugi proponowany kierunek analiz to porównanie procesu wypracowywania feministycznej samoidentyfikacji mężczyzn jako dyspozycji klasowej z charakterystycznym dla kultury terapeutycznej indywidualistycznym projektem siebie. Analizy takie mogłyby być pomocne w rozstrzygnięciu, w jakim stopniu indywidualistyczny projekt siebie może przyczynić się do 
rewolucyjnego zaangażowania społecznego w dobie procesów urynkowienia niektórych progresywnych elementów polityk społecznych.

\section{BIBLIOGRAFIA}

Anderson Eric, 2009, Inclusive Masculinity: The Changing Nature of Masculinities, Routledge, Oxford.

Anderson Eric, McCormack Mark, 2016, Inclusive Masculinity Theory: Overview, Reflection and Refinement, „Journal of Gender Studies” [October 23 on line].

Arcimowicz Krzysztof, 2008, Przemiany męskości w kulturze wspótczesnej, w: Małgorzata Fuszara (red.), Nowi mężczyźni? Zmieniające się modele męskości we wspótczesnej Polsce, Trio, Warszawa.

Bednarek Joanna, 2014, Przedmowa: Nowa kartografia wspótczesności, w: Rosi Braidotti, Po człowieku, Wydawnictwo Naukowe PWN, Warszawa.

Berger Peter L., Luckmann Thomas, 1983, Społeczne tworzenie rzeczywistości, tłum. Józef Niżnik, Państwowy Instytut Wydawniczy, Warszawa.

Bourdieu Pierre, 2004, Męska dominacja, tłum. Lucyna Kopciewicz, Oficyna Naukowa, Warszawa.

Bridges Tristan, Pascoe C. J., 2014, Hybrid Masculinities: New Directions in the Sociology of Men and Masculinities, „Sociology Compass”, t. 8(3), s. 246-258.

Butler Judith, 2008, Uwiktani w pteć, tłum. Karolina Krasuska, Wydawnictwo Krytyki Politycznej, Warszawa.

Ciaputa Ewelina, Wojnicka Katarzyna (red.), 2011, Karuzela z mężczyznami. Problematyka męskości w polskich badaniach społecznych, Oficyna Wydawnicza Impuls, Kraków.

Connell Raewyn, 2005, Masculinities, University of California Press, Berkeley.

Connell Raewyn, 2009, Gender in World Perspective, Polity Press, Cambridge.

de Boise Sam, 2015, Men, Masculinity, Music and Emotions, Palgrave Macmillan, London.

de Boise Sam, 2017, The Personal Is Political ... Just Not Always Progressive: Affective Interruptions and Their Promise for CSMM, „NORMA. International Journal for Masculinity Studies” [May 12 on line].

de Boise Sam, Hearn Jeff, 2017, Are Men Getting More Emotional? Critical Sociological Perspectives on Men, Masculinities and Emotions, „The Sociological Review”, t. 65(4), s. 779-796.

Elliott Karla, 2016, Caring Masculinities: Theorizing an Emerging Concept, „Men and Masculinities", t. 19(3), s. 240-259.

Gilligan Caroll, 2015, Innym głosem, tłum. Barbara Szelewa, Wydawnictwo Krytyki Politycznej, Warszawa.

Golińska Dominika, 2008, Feminizm nie tylko dla kobiet. Rzecz o polskich feministach, w: Barbara Płonka-Syroka (red.), Stereotypy i wzorce męskości w różnych kulturach świata, Wydawnictwo DiG, Warszawa.

Gordon Steven, 1990, Social Structural Effects on Emotions, w: Kemper Theodore D. (red.), Research Agendas in the Sociology of Emotions, SUNY, New York.

Hearn Jeff, 2018, Od męskości hegemonicznej do hegemonii mężczyzn, w: Adam Dziadek (red.), Formy męskości 3, Wydawnictwo IBL PAN, Warszawa.

Hill Collins Patricia, 2006, Czarna myśl feministyczna w macierzy dominacji, tłum. Adam Ostolski, w: Marek Ziółkowski, Lech M. Nijakowski, Jerzy Szacki, Aleksandra Jasińska-Kania (red.), Wspótczesne teorie socjologiczne, t. 2, Scholar, Warszawa. 
hooks bell, 2004, The Will to Change: Men, Masculinity and Love, Atria Books, New York.

hooks bell, 2013, Teoria feministyczna. Od marginesu do centrum, tłum. Ewa Majewska, Wydawnictwo Krytyki Politycznej, Warszawa.

Irigaray Luce, 1993, Sexual Difference, w: Luce Irigaray, An Ethics of Sexual Difference, Continuum, London-New York.

Kimmel Michael, 2013, Angry White Men: American Masculinity at the End of an Era, Nation Books-Perseus Books, New York.

Kluczyńska Urszula, Wojnicka Katarzyna, 2015, Wymiary męskości, „InterAlia. Pismo poświęcone studiom queer", nr 10.

Kwaśny Barbara, 2009, Polskie studia nad męskościa, „Zeszyty Etnologii Wrocławskiej”, nr 1.

Lutz Catherine, 2012, Emocje, rozum i wyobcowanie. Emocje jako kategoria kulturowa, w: Małgorzata Rajtar, Justyna Starczuk (red.), Emocje w kulturze, Wydawnictwa Uniwersytetu Warszawskiego, Warszawa.

Messner Michael, Greenberg Max, Peretz Tal, 2015, Some Men: Feminist Allies and the Movement to End Violence against Women, Oxford University Press, New York.

Rubin Gayle, 1975, The Traffic in Women, w: Raina R. Reiter (red.), Toward an Anthropology of Women, Monthy Review Press, New York.

Sawicka Maja, 2015, Pojęcie kultury emocjonalnej jako narzędzie analizy socjologicznej, „Kultura i Społeczeństwo", nr 1, s. 181-196.

Tong Putnam Rosemarie, 2002, Myśl feministyczna. Wprowadzenie, tłum. Jarosław Mikos, Bożena Umińska, Wydawnictwo Naukowe PWN, Warszawa.

Wouters Cas, 2004, Sex and Manners: Female Emancipation in the West 1890-2000, Sage Publications, London.

FEMINISTS:

EMOTIONAL CULTURE, FEMINISM, AND CHANGES IN MASCULINITY

\author{
Paweł Bagiński \\ (Warsaw University)
}

Abstract

This paper addresses issues of feminism, masculinity, and the emotional culture of middle-class men who self-declare as feminists. The author discusses feminist theories on masculinity and its relations with femininity, critical theories of masculinity, and the role of emotional culture in the expression of masculinity. Feminists have proposed a dimorphic definition of feminism as a political movement and personal attitude critical of masculine domination. The critique of patriarchal, hegemonic masculinity has led feminists either to identify with "positive" masculinity or to reject masculinity for a post-gender narrative or material-discursive fact of "being a man," which suggests an inadequacy of the sex/gender distinction in the description of gender identity. The identification with feminism allows men to avoid the crisis of traditional masculinity and the perspective of gendered emotions, as well as to gain insight into gendered determinants of emotional expression. 
Key words / słowa kluczowe

gender studies, feminism / feminizm, men and masculinity / mężczyźni i męskość, emotional culture / kultura emocjonalna, identity / tożsamość, the sociology of emotions / socjologia emocji 